\title{
The first assessment of the stress inducible defense of Leucaena leucocephala with acaricidal potential effect against Rhipicephalus (Boophilus) microplus (Acari: Ixodidae)
}

Primeira avaliação de extratos proteicos de Leucaena leucocephala induzidos por injúria mecânica com atividade carrapaticida sobre Rhipicephalus (Boophilus) microplus (Acari: Ixodidae)

Lêdia Feitosa Wanderley ${ }^{1}$; Karla Lílian Rodrigues Batista ${ }^{1}$; Jorgiane Furtado de Carvalho²; Aldilene da Silva Lima²; Gabriel Alves Landulfo²; Alexandra Martins dos Santos Soares' ${ }^{1}$ Livio Martins Costa Junior ${ }^{2 *}$

${ }^{1}$ Curso de Engenharia Química, Universidade Federal do Maranhão - UFMA, Săo Luís, MA, Brasil

${ }^{2}$ Departamento de Patologia, Universidade Federal do Maranhão - UFMA, São Luís, MA, Brasil

Received January 19, 2017

Accepted April 13, 2017

\begin{abstract}
Plants respond to wounding caused by mechanical stress or herbivory by synthesizing defense proteins. There are no studies reporting the action of induced plant proteins against ticks. The aim of this study was to investigate the effect of mechanically wounded Leucaena leucocephala leaves against Rhipicephalus (Boophilus) microplus. Initially, we carried out time course experiments to evaluate the impact of mechanical wounding on the protein content and the peroxidase, catalase and protease inhibitor activities in L. leucocephala. We then evaluated the acaricidal activity on $R$. (B.) microplus from protein extract collected from $L$. leucocephala after mechanical wounding. L. leucocephala leaves were artificially wounded, and after 6,12, 24 and 48h, the leaves were collected for protein extraction. Quantitative and qualitative analyses of the proteins were performed. The protein content and peroxidase and protease activities increased $12 \mathrm{~h}$ after wounding, and the acaricidal activity of this protein extract was evaluated using engorged $R$. (B.) microplus females. The protein extract obtained after wounding reduced egg production (8.5\%) compared to those without wounding. Furthermore, the extract reduced egg hatching by $47.7 \%$ and showed an overall efficacy of $56.3 \%$ at $0.1 \mathrm{mgP} / \mathrm{mL}$ of the protein. We demonstrated that $L$. leucocephala defensive proteins could be effective against $R$. (B.) microplus.
\end{abstract}

Keywords: Mechanical stress, plant protein, induced defense, acaricide, tick.

\section{Resumo}

As plantas respondem a injúria causada por estresse mecânico ou por ataque de herbívoros através da síntese de proteínas de defesa. Não há estudos de proteínas induzidas de plantas contra carrapatos. O objetivo deste estudo foi verificar a atividade acaricida de extratos protéicos de folhas Leucaena leucocephala após injúria mecânica, sobre Rhipicephalus (Boophilus) microplus. Inicialmente foram conduzidos experimentos em diferentes intervalos de tempo para avaliar o impacto da injúria mecânica no conteúdo de proteína, atividade de peroxidase, catalase e inibidor de protease de L. leucocephala. Em seguida foi avaliada a atividade acaricida sobre $R$. (B.) microplus de um extrato protéico após injúria mecânica. Folhas de L. leucocephala foram artificialmente feridas e após $6,12,24$ e 48h, as folhas foram coletadas para extração de proteínas. Análises quantitativas e qualitativas das proteínas foram realizadas. A quantidade de proteína e atividades de peroxidase e protease aumentaram $12 \mathrm{~h}$ após a injúria. $\mathrm{O}$ extrato proteico obtido após injúria (12h) reduziu a produção de ovos $(8,5 \%)$ em comparação com extratos de plantas sem injúria. O extrato reduziu $47,7 \%$ a eclosáo de ovos e apresentou eficácia geral de $56,3 \%$ a 0,1 miligrama de proteína por $\mathrm{mL}(\mathrm{mgP} / \mathrm{mL})$. Apresentamos que proteínas de defesa de $L$. leucocephala podem ter atividade sobre $R$. (B.) microplus.

Palavras-chave: Estresse mecânico, proteínas de planta, defesa induzida, acaricida, carrapato.

*Corresponding author: Livio Martins Costa Junior. Departamento de Patologia, Universidade Federal do Maranhão - UFMA, Av. dos Portugueses, 1966, Bacanga, CEP 65080-805, São Luís, MA, Brasil.

e-mail: livio.martins@ufma.br 


\section{Introduction}

Throughout their evolutionary history, the constant exposure of plants to adverse conditions has led to the development of a complex system of defense responses to biotic and abiotic stressors; this system consists of diverse morphological, physiological, biochemical and molecular changes for the plants' acclimation (WANG et al., 2003; BONALDO et al., 2005). Plant defense can be constitutive, which occurs normally in the plant's metabolism, or it can be induced after stressful conditions (WAR et al., 2012).

The study of abiotic stress in plants has advanced considerably in recent years, and diverse studies have identified protein changes in response to different stress, such as cold, heat, drought, salinity and mechanical wounding (RIZHSKY et al., 2004; KOSOVÁ et al., 2011). Changes in protein abundance and the expression profiles of specific genes/proteins in response to wounding have been reported in plants, such as papaya (LOOZE et al., 2009; PAN \& JIANG, 2014), rice (RANI \& JYOTHSNA, 2010), turfgrasses (GULSEN et al., 2010), maize (LEWANDOWSKAGNATOWSKA et al., 2011), and apple (BURON-MOLES et al., 2014). The changes in the proteome composition after the wound healing process are related to the increased expression of several proteins that are related to the stress response, such as protease inhibitors, pathogenesis-related proteins, peroxidases, chitinases and proteases (KOSOVÁ et al., 2011).

It is known that plants display bioactive molecules that can act in response to parasites. Several studies demonstrated the activity of plant compounds on different species of parasites, such as ticks (SOARES et al., 2010; LIMA et al., 2014; CASTRO et al., 2014; GEORGE et al., 2014; LAGE et al., 2015). To obtain natural bioactive compounds that are less harmful to the environment, animals and humans, the use of plant products has become an alternative method to synthesize chemicals for the control of ticks (AMARAL et al., 2002; ELLSE \& WALL, 2014), including Rhipicephalus (Boophilus) microplus.

The cattle tick $R$. (B.) microplus is the most common parasite in livestock in tropical and subtropical regions (GRISI et al., 2014). Ticks are generally controlled with synthetic acaricides, but indiscriminate use has increased the frequency of resistance to these chemicals (RODRÍGUEZ-VIVAS et al., 2006; CASTRO-JANER et al., 2010; MILLER et al., 2013).

Native to Central America, Leucaena leucocephala can be found in many tropical and subtropical regions of the world (NEHDI et al., 2014) and is often used as forage for livestock (PANDEY \& KUMAR, 2013). L. leucocephala is a tannin-rich plant with anti-parasitic activity against ticks and nematodes; almost all studies on this plant have focused on secondary metabolites (CUNHA et al., 2003; ALONSO-DÍAZ et al., 2008; AHMED et al., 2010; OLIVEIRA et al., 2011; FERNÁNDEZ-SALAS et al., 2011; HERNANDEZ et al., 2014; SOARES et al., 2015).

There are no studies indicating the possibility of acaricidal activity from proteins in L. leucocephala leaves nor are there any studies focused on the plant's induced proteins by mechanical wounding. Thereby, the aim of this study was to verify the acaricidal activity of the protein extract from $L$. leucocephala leaves after mechanical wounding against $R$. (B.) microplus.

\section{Materials and Methods}

\section{Plant material, protein extraction and quantification}

Mature seeds of the L. leucocephala plant were obtained commercially. After breaking dormancy with water (PASSOS et al., 1988), they were cultivated in plastic pots containing black soil and were grown in a greenhouse.

Leaves of plants at the three-leaf stage (15 days) were subjected to mechanical injuries using anatomical steel serrated forceps $(140 \mathrm{~mm})$. At specific intervals after the wounding $(6,12,24$ and $48 \mathrm{~h})$, leaves of five plants per treatment at each time were harvested, frozen in liquid nitrogen and ground to a fine powder. Polyvinylpolypyrrolidone (PVPP) at 2\% (w/w) was added for the removal of phenolics compounds. As the control group, L. leucocephala leaves from unwounded plants were subjected to the same procedure.

The proteins of the leaves were extracted with $100 \mathrm{mM}$ potassium phosphate ( $\mathrm{pH} 7.0$ ) containing $75 \mathrm{mM} \mathrm{NaCl}$ in the ratio $1: 10(\mathrm{w} / \mathrm{v})$. The slurry was centrifuged for $30 \mathrm{~min}$. at $15,000 \mathrm{x} \mathrm{g}$ at $4{ }^{\circ} \mathrm{C}$, and the supernatant was collected and centrifuged under the same conditions. The final supernatants were collected, classified as protein extracts of leaves (PELs) and stored at $-20{ }^{\circ} \mathrm{C}$ for assays and protein analysis. All procedures were carried out in five replicates.

The soluble proteins of the PELs were quantified according to Bradford (1976), using bovine serum albumin (BSA) as the standard. The soluble protein content of the extracts was expressed as milligram of protein per gram of fresh mass (mgP/gMF) and was calculated using following equation: protein content $(\mathrm{mgP} / \mathrm{gMF})=[$ protein concentration $(\mathrm{mg} / \mathrm{mL})] \mathrm{x}$ buffer volume $(\mathrm{mL}) /$ leaf weight $(\mathrm{g})$.

\section{Gel electrophoresis (SDS-PAGE)}

SDS-PAGE (15\%) was performed according to Laemmli (1970), and protein bands were revealed with silver nitrate. A Molecular Weight Marker kit (code 17044601 from GE Healthcare, Buckinghamshire, UK) was used as the protein markers (MW of 97, 66, 45, 30, 20 and $14 \mathrm{kDa}$ ).

\section{Catalase, peroxidase, protease and protease inhibitor assays}

The catalase activity (CAT) of the PELs was measured by the decrease in the absorbance at $240 \mathrm{~nm}$ for four min. every 10 seconds (HAVIR \& MCHALE, 1987; PEIXOTO et al., 1999). A change of 0.01 absorbance unit per min. was considered a unit of catalase activity (1 UA). Catalase activity was expressed as the activity unit per gram of fresh mass (AU/gMF).

Peroxidase activity (POD) was determined following the methodology described by Urbanek et al. (1991). The variation of 1.0 absorbance unit per min. was assumed to be 1.0 unit of peroxidase activity. The peroxidase activity was expressed as the activity unit per gram of fresh mass (AU/gMF). 
Total proteolytic activity of PELs was examined using azocasein as a nonspecific substrate (XAVIER-FILHO et al., 1989). One unit of activity (UA) was defined as the amount of enzyme capable of increasing absorbance by $420 \mathrm{~nm}$ at $0.01 \mathrm{~mL}^{-1}$ in $60 \mathrm{~min}$.

Cysteine proteinase inhibitor activity in PELs was determined by measuring the inhibition of papain activity with benzoyl-DL-arginine- $\beta$ naphthylamide (BANA) as the substrate (ABE et al., 1992). One unit of inhibitory activity (UI) was defined as the decrease of 0.01 absorbance units at $540 \mathrm{~nm} / \mathrm{mL} / \mathrm{min}$ when compared with the control (papain activity in the absence of the inhibitor).

\section{Adult immersion test (AIT)}

The sensitivity of engorged $R$. (B.) microplus females to PELs was determined using the adult immersion test (AIT) described by Drummond et al. (1973). The PELs from the leaves collected at 12 hours after the initiation of the experiment were chosen because showed increased protein content, peroxidase and protease. Engorged $R$. (B.) microplus females were collected from artificially infested calves. Groups of ten engorged female ticks were each individually weighed to obtain groups with similar weights. The ticks were immersed for five min. in four $\mathrm{mL}$ of PELs from wounded and unwounded plants (control) at $0.1 \mathrm{mg} / \mathrm{mL}$.

The engorged females were subsequently dried on a paper towel, placed in Petri dishes and maintained in a biochemical oxygen demand incubator at $27 \pm 1{ }^{\circ} \mathrm{C}$ with $\mathrm{RH} \geq 80 \%$ for 15 days for further evaluation of oviposition and more 30 days to hatchability of their eggs. Hatchability was estimated from the average of three count of eggs and larvae by using a stereomicroscope.

The egg production index (EPI), the reduction in oviposition, and the efficiency of the extract (EP) were calculated according to the following formulas: EPI = (weight of eggs/ weight of engorged female) $\times 100$ (BENNETT, 1974); reduction in oviposition $=($ EPI control group - EPI experimental group $/$ EPI control group) $\times 100$ (ROULSTON et al., 1968); reproduction efficiency index $(\mathrm{REI})=($ egg mass weight $\times$ egg hatching (percentage $) /$ engorged females weight $) \times 20,000 ; \mathrm{EP}=(\mathrm{REI}$ control $-\mathrm{REI}$ treated $) /$ (REI control×100) (DRUMMOND et al., 1973).

\section{Statistical analysis}

The protein content and enzymatic activity of proteins related to the wounded plant response of the PELs were statistically analyzed for normality by a Shapiro-Wilks test, and the averages \pm standard deviation were compared to the control group with a Student's T-test with the significance level of 5\%.

\section{Results}

Quantitative and qualitative changes in the protein content were observed in the PELs of wounded plants (Figure 1). The average increase of protein content in the PELs after wounding was $4.47 \mathrm{mg}$ protein per gram of fresh mass. Significant increases of protein content $(\mathrm{p} \leq 0.05)$ were observed from PEL groups at 6 (increase of 55.3\%), 12 (increase of 46.4\%) and 48 hours (increase of $43.6 \%$ ) after wounding (Figure 1). The levels of two proteins increased in the 12, 24 and 48 hour groups.

Protease inhibitor and catalase activities were not detected in the PELs of L. leucocephala. Mechanical wounding increased the peroxidase activity in all analyzed time groups (Figure 2A). Proteolytic activity was significantly increased (54.0\%) only in the PELs from the $12 \mathrm{~h}$ after wounding group (Figure 2B).

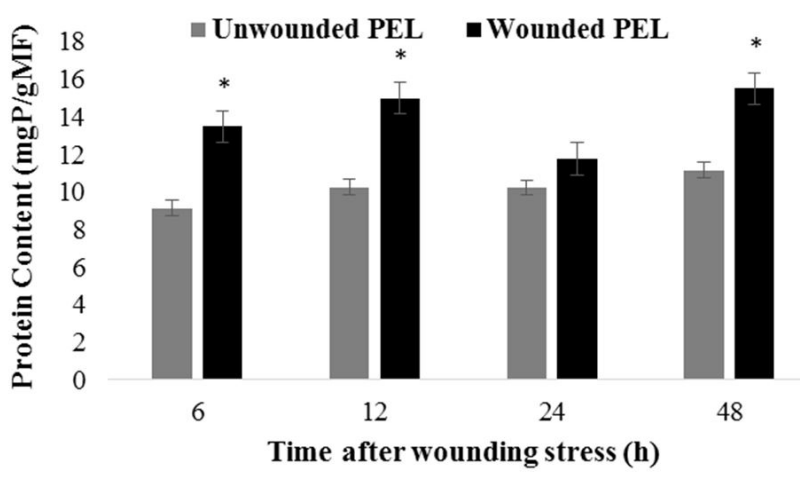

Figure 1. Assessment of protein content of the protein extracts of leaves (PELs) from Leucaena leucocephala plant. The unit mgP/gMF represents milligram of protein per gram of fresh mass. Time after wounding of the horizontal line corresponds to the periods that the leaves were harvested after the mechanical injury, forming the treatment group. Data are mean \pm standard deviation of four independent experiments. ${ }^{*}$ Data differ significantly $(\mathrm{p}<0.05)$.

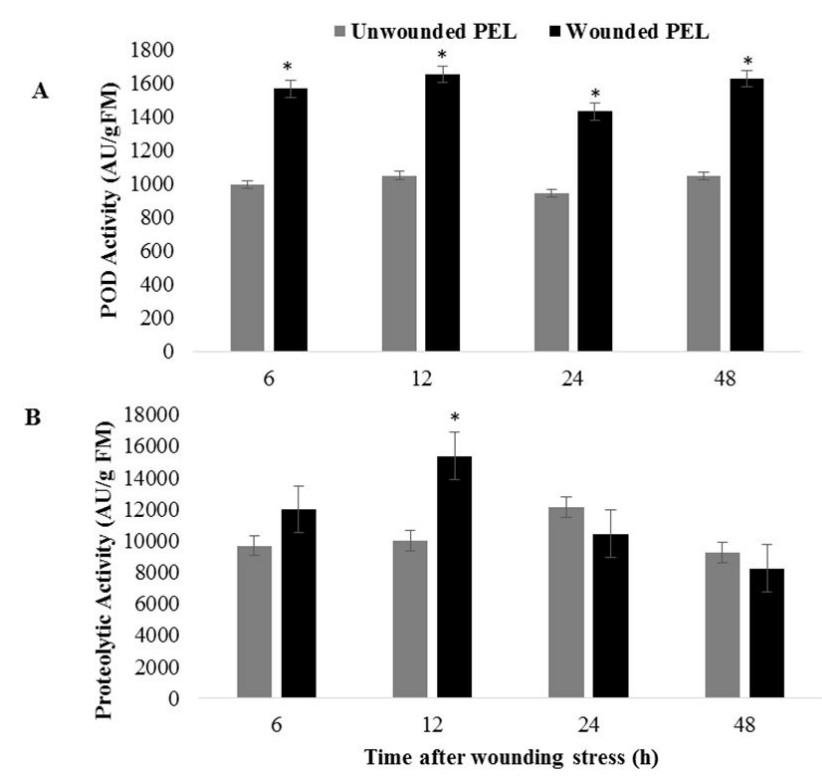

Figure 2. Peroxidase activity (POD) (A) and proteolytic activity (B) of the protein extracts of leaves (PELs) in response to mechanical wounding in a time course experiment $(6,12,24$ and 24 hrs after the wounding). Time after wounding of the horizontal line corresponds to the periods that the leaves were harvested after mechanical injury, forming the treatment group. The peroxidase and proteolytic activities were expressed as activity unit per gram of fresh mass (AU/gMF). Data are mean \pm standard deviation of four independent experiments. *Data differ significantly $(\mathrm{p}<0.05)$. 
The PELs obtained from leaves collected 12 hours after wounding and from leaves of unwounded plants were used in AIT at $0.1 \mathrm{mg} / \mathrm{mL}$. The protein extract obtained after wounding reduced egg production (8.5\%) when compared to those without wounding. Furthermore, the extract reduced egg hatching by $47.7 \%$, and showed an overall efficacy of $56.3 \%$.

\section{Discussion}

Although peptides from poisons and fungi have demonstrated activity against ticks (MUKHERJEE et al., 2006; MORAIS-URANO et al., 2012), and plant defense proteins have been effectively used against phytophagous insects (MARTINEZ et al., 2016), there are no studies that have investigated the activities of plant defense proteins against ticks.

To associate induced L. leucocehala defense proteins with the potential for tick control, we performed a test on engorged $R$. (B.) microplus females with PELs obtained from leaves. PELs collected $12 \mathrm{~h}$ after wounding did not show a significant reduction in egg production; however, they showed a $47.7 \%$ inhibition of egg hatching and an overall efficacy of $56.3 \%$. L. leucocephala leaf extract, rich in secondary metabolites, was observed to be effective against the larvae, but not against the engorged females of $R$. (B.) microplus (FERNÁNDEZ-SALAS et al., 2011).

Our results showed that the acaricide effect of PELs from wounded leaves coincided with high protease activity, however other studies are needed to confirm the acaricide properties of this enzyme. The peroxidase enzyme is an important component of the immediate response of plants to insect damage (RANI \& JYOTHSNA, 2010; GULSEN et al., 2010). The same results have been observed for different types and classes of proteases; these enzymes have many different roles in the plant's defense against insect feeding, such as directly degrading proteins from the invader, releasing peptide-based toxins or activating enzymes from their precursor proteins (VAN DER HOORN \& JONES, 2004).

In the present study, we verified changes in the protein content, pattern and enzyme activities of $L$. leucocephala leaves in response to mechanical wounding in a time course experiment. The protein content was increased, and the protein profile was altered after wounding. Although catalase and protease inhibitory activities were not detected, the activities of peroxidase and protease increased 6 to 48 hours and 12 hours after wounding, respectively. Similar alterations in response to herbivory and mechanical stress were observed in rice (RANI \& JYOTHSNA, 2010) and apple (BURON-MOLES et al., 2014).

Mechanical stressors, such as injuries and wounding, can activate the defense mechanisms of the plant to induce local and/or systemic responses (KESSLER \& BALDWIN, 2002). The defense mechanism is orchestrated by changes in protein expression, in which the plant is able to overexpress or inhibit the expressions or actions of molecules such as protease, protease inhibitor, catalase, peroxidase, chitinase and lipoxygenase (WANG et al., 2003; AHSAN et al., 2007; GULSEN et al., 2010; KOSOVÁ et al., 2011).

The increase of peroxidase activity in the wounded L. leucocephala plant can be attributed to the detoxification mechanism of peroxides, the healing induced by wounding and the defense mechanism against damage (ALMAGRO et al., 2009; RANI \& JYOTHSNA, 2010). In this study, we evaluated peroxidase activity as a stress marker (DÍAZ \& MERINO, 1998; TSCHARNTKE et al., 2001). Catalase is part of another enzyme group known to be antioxidant enzymes involved in the reduction of oxidative stress (WAR et al., 2013); however, we did not observe catalase activity in the protein extracts from the L. leucocephala plant. A similar finding was observed for the activity of protease inhibitors, which was not identified in our results.

The increase of proteolytic activity can be associated with the involvement of proteases in amino acids recycled for the synthesis of protective proteins and/or defense molecules against herbivory (GREEN \& RYAN, 1972; PECHAN et al., 2000; VAN DER HOORN \& JONES, 2004). In corn, an accumulation of a 33-kD cysteine protease called Mir1-CP has been observed in response to the feeding of lepidopterous larvae and the mechanical injury (PECHAN et al., 2000).

Hence, the induced wounding in leaves from the L. leucocephala plant causes enzymatic changes and alters the protein content. Furthermore, the protein extract of wounded leaves can suggest interferences in the $R$. (B.) microplus cycle by reducing the percentage of hatched eggs. The inducible proteins could be a novel approach for tick control. Further research should be conducted to discern the proteins which is involved in the acaricide effect.

\section{Acknowledgements}

The authors wish to thank CNPq (The Brazilian National Council for Scientific and Technological Development) for awarding a fellowship to L.M. Costa-Júnior, CAPES (Brazilian Federal Agency for Support and Evaluation of Graduate Education) for the scholarship to L.F. Wanderley and G.A. Landulfo and FAPEMA (Maranhão State Research Foundation) for the scholarship to K.L.R. Batista and J.F. Carvalho. We also thank CNPq and FAPEMA for financial support.

\section{References}

Abe M, Abe K, Kuroda M, Arai S. Corn Kernel cysteine proteinase inhibitor as a novel cystatin superfamily member of plant origin: molecular cloning and expression studies. Eur J Biochem 1992; 209(3): 933-937. PMid:1425699. http://dx.doi.org/10.1111/j.1432-1033.1992.tb17365.x.

Ahmed ZM, Dawar S, Tariq M, Zaki MJ. Effect of local tree seeds in the control of root knot nematode Meloidogyne javanica (Treub) chitwood and growth promotion of chickpea (Cicer arietinum L.) and mung bean (Vigna radiata L.). Acta Agrobot 2010; 63(1): 197-203. http://dx.doi. org/10.5586/aa.2010.022.

Ahsan N, Lee DG, Lee SH, Kang KY, Bahk JD, Choi MS, et al. A comparative proteomic analysis of a tomato leaves in response to waterlogging stress. Physiol Plant 2007; 131(4): 555-570. PMid:18251847. http://dx.doi. org/10.1111/j.1399-3054.2007.00980.x.

Almagro L, Ros LG, Belchi-Navarro S, Bru R, Barceló AR, Pedrenó MA. Class III peroxidases in plant defence reactions. J Exp Bot 2009; 60(2): 377-390. PMid:19073963. http://dx.doi.org/10.1093/jxb/ern277. 
Alonso-Díaz MA, Torres-Acosta JFJ, Sandoval-Castro CA, CapetilloLeal C, Brunet S, Hoste H. Effects of four tropical tanniniferous plant extracts on the inhibition of larval migration and the exsheathment process of Trichostrongylus colubriformis infective stage. Vet Parasitol 2008; 153(1-2): 187-192. PMid:18304736. http://dx.doi.org/10.1016/j. vetpar.2008.01.011.

Amaral DR, Oliveir ADF, Campos VP, Carvalho DA. Efeito de alguns extratos vegetais na eclosão, mobilidade, mortalidade e patogenicidade de Meloidogyne exigua do cafeeiro. Nematol Bras 2002; 26(1): 43-48.

Bennett GF. Oviposition of Boophilus microplus (Canestrini) (Acarida: Ixodidae). I. Influence of tick size on egg production. Acarologia 1974; 16(1): 52-61. PMid:4463680.

Bonaldo SM, Pascholati SF, Romeiro RS. Indução de resistência: noções básicas e perspectivas. In: Cavalcanti LS, Di Piero RM, Cia P, Pascholati SF, Resende MLV, Romeiro RS. Indução de resistência em plantas a patógenos e insetos. Piracicaba: FEALQ; 2005. p. 11-28.

Bradford MM. Rapid and sensitive method for the quantitation of microgram quantities of protein utilizing the principle of protein-dye binding. Anal Biochem 1976; 72(1-2): 248-254. PMid:942051. http:// dx.doi.org/10.1016/0003-2697(76)90527-3.

Buron-Moles G, Torres R, Amoako-Andoh F, Viñas I, Teixidó N, Usall $\mathrm{J}$, et al. Analysis of changes in protein abundance after wounding in 'Golden Delicious' apples. Post Biol Tech 2014; 87: 51-60. http://dx.doi. org/10.1016/j.postharvbio.2013.07.039.

Castro KNC, Lima DF, Vasconcelos LC, Leite JRSA, Santos RC, Paz AA No, et al. Acaricide activity in vitro of Acmella oleracea against Rhipicephalus microplus. Parasitol Res 2014; 113(10): 3697-3701. PMid:25033813. http://dx.doi.org/10.1007/s00436-014-4034-2.

Castro-Janer E, Martins JR, Mendes MC, Namindome A, Klafke GM, Schumaker TTS. Diagnoses of fipronil resistance in Brazilian cattle ticks (Rhipicephalus (Boophilus) microplus) using in vitro larval biossays. Vet Parasitol 2010; 173(3): 300-306. PMid:20688434. http://dx.doi. org/10.1016/j.vetpar.2010.06.036.

Cunha FR, Oliveira DF, Campos VP. Extratos vegetais com propriedades nematicidas e purificação do princípio ativo do extrato de Leucaena leucocephala. Fitopatol Bras 2003; 28(4): 438-441. http://dx.doi. org/10.1590/S0100-41582003000400017.

Díaz J, Merino F. Wound-induced shikimate dehydrogenase and peroxidase related to lignification in pepper (Capsicum annuum L.) leaves. J Plant Physiol 1998; 152(1): 51-57. http://dx.doi.org/10.1016/ S0176-1617(98)80101-6.

Drummond RO, Ernst SE, Trevino JL, Gladney WJ, Graham OH. Boophilus annulatus and B. microplus: laboratory tests for insecticides. J Econ Entomol 1973; 66(1): 130-133. PMid:4690254. http://dx.doi. org/10.1093/jee/66.1.130.

Ellse L, Wall R. The use of essential oils in veterinary ectoparasite control: a review. Med Vet Entomol 2014; 28(3): 233-243. PMid:24147451. http:// dx.doi.org/10.1111/mve.12033.

Fernández-Salas A, Alonso-Díaz MA, Acosta-Rodríguez R, Torres-Acosta JFJ, Sandoval-Castro CA, Rodríguez-Vivas RI. In vitro acaricidal effect of tannin-rich plants against the cattle tick Rhipicephalus (Boophilus) microplus (Acari: Ixodidae). Vet Parasitol 2011; 175(1): 113-118. PMid:20947253. http://dx.doi.org/10.1016/j.vetpar.2010.09.016.

George DR, Finn RD, Graham KM, Sparagano OA. Present and future potential of plant-derived products to control arthropods of veterinary and medical significance. Parasit Vectors 2014; 7(1): 28. PMid:24428899. http://dx.doi.org/10.1186/1756-3305-7-28.

Green TR, Ryan CA. Wound-induced proteinase inhibitor in plant leaves: a possible defense mechanism against insects. Science 1972; 175(4023): 776-777. PMid:17836138. http://dx.doi.org/10.1126/ science. 175.4023 .776

Grisi L, Leite RC, Martins JRS, Barros ATM, Andreotti R, Cancado PHD, et al. Reassessment of the potential economic impact of cattle parasites in Brazil. Brazilian. Rev Bras Parasitol Vet 2014; 23(2): 150156. PMid:25054492. http://dx.doi.org/10.1590/S1984-29612014042.

Gulsen O, Eickhoff T, Heng-Moss T, Shearman R, Baxendale F, Sarath $\mathrm{G}$, et al. Characterization of peroxidase changes in resistant and susceptible warm-season turfgrasses challenged by Blissus occiduus. Arthropod-Plant Interact 2010; 4(1): 45-55. http://dx.doi.org/10.1007/s11829-010-9086-3.

Havir EA, McHale NA. Biochemical and developmental characterization of multiple forms of catalase in tobacco leaves. Plant Physiol 1987; 84(2): 450-455. PMid:16665461. http://dx.doi.org/10.1104/pp.84.2.450.

Hernandez PM, Salem AZM, Elghandour MMMY, Cipriano-Salazar M, Cruz-Lagunas B, Camacho LM. Anthelmintic effects of Salix babylonica and Leucaena leucocephala Lam. extracts in growing lambs. Trop Anim Health Prod 2014; 46(1): 173-178. PMid:24077919. http://dx.doi. org/10.1007/s11250-013-0471-7.

Kessler A, Baldwin IT. Plant responses to insect herbivory: the emerging molecular analysis. Annu Rev Plant Biol 2002; 53(1): 299-328. PMid:12221978. http://dx.doi.org/10.1146/annurev.arplant.53.100301.135207.

Kosová K, Vítámvás P, Prášil IT, Renaut J. Plant proteome changes under abiotic stress-Contribution of proteomics studies to understanding plant stress response. J Proteomics 2011; 74(8): 1301-1322. PMid:21329772. http://dx.doi.org/10.1016/j.jprot.2011.02.006.

Laemmli UK. Cleavage of structural proteins during the assembly of the head of bacteriophage T4. Nature 1970; 227(5259): 680-685. PMid:5432063. http://dx.doi.org/10.1038/227680a0.

Lage TCA, Montanari RM, Fernandes SA, Monteiro CMO, Senra TDOS, Zeringota V, et al. Chemical composition and acaricidal activity of the essential oil of Baccharis dracunculifolia De Candole (1836) and its constituents nerolidol and limonene on larvae and engorged females of Rhipicephalus microplus (Acari: Ixodidae). Exp Parasitol 2015; 148: 2429. PMid:25448290. http://dx.doi.org/10.1016/j.exppara.2014.10.011.

Lewandowska-Gnatowska E, Johnston ML, Antoine W, Szczegielniak J, Muszyńska G, Miernyk JA. Using multiplex-staining to study changes in the maize leaf phosphoproteome in response to mechanical wounding. Phytochemistry 2011; 72(10): 1285-1292. PMid:21334701. http://dx.doi. org/10.1016/j.phytochem.2011.01.030.

Lima AS, Sousa JGN Fo, Pereira SG, Guillon GMSP, Santos LS, Costa LM Jr. Acaricide activity of different extracts from Piper tuberculatum fruits against Rhipicephalus microplus. Parasitol Res 2014; 113(1): $107-$ 112. PMid:24221883. http://dx.doi.org/10.1007/s00436-013-3632-8.

Looze Y, Boussard P, Huet J, Vandenbussche G, Raussens V, Wintjens R. Purification and characterization of a wound-inducible thaumatin-like protein from the latex of Carica papaya. Phytochemistry 2009; 70(8): 970-978. PMid:19527911. http://dx.doi.org/10.1016/j.phytochem.2009.05.005.

Martinez M, Santamaria ME, Diaz-Mendoza M, Arnaiz A, Carrillo L, Ortego F, et al. Phytocystatins: defense proteins against phytophagous insects and acari. Int J Mol Sci 1747; 2016(17): 1-16. PMid:27775606.

Miller RJ, Almazán C, Ortíz-Estrada M, Davey RB, George JE, De León AP. First report of fipronil resistance in Rhipicephalus (Boophilus) microplus 
of Mexico. Vet Parasitol 2013; 191(1-2): 97-101. PMid:23026557. http:// dx.doi.org/10.1016/j.vetpar.2012.08.011.

Morais-Urano RP, Chagas ACS, Berlinck RGS. Acaricidal action of destruxins produced by a marine-derived Beauveria felina on the bovine tick Rhipicephalus (Boophilus) microplus. Exp Parasitol 2012; 132(3): 362366. PMid:22955115. http://dx.doi.org/10.1016/j.exppara.2012.08.011.

Mukherjee AK, Sollod BL, Wikel SK, King GF. Orally active acaricidal peptide toxins from spider venom. Toxicon 2006; 47(2): 182-187. PMid:16330063. http://dx.doi.org/10.1016/j.toxicon.2005.10.011.

Nehdi IA, Sbihi H, Tan CP, Al-Resayes SI. Leucaena leucocephala (Lam.) de Wit seed oil: characterization and uses. Ind Crops Prod 2014; 52: 582 587. http://dx.doi.org/10.1016/j.indcrop.2013.11.021.

Oliveira LMB, Bevilaqua CML, Macedo ITF, Morais SM, Monteiro MVB, Campello CC, et al. Effect of six tropical tanniferous plant extracts on larval exsheathment of Haemonchus contortus. Rev Bras Parasitol Vet 2011; 20(2): 155-160. PMid:21722491. http://dx.doi.org/10.1590/ S1984-29612011000200011.

Pan LJ, Jiang L. Identification and expression of the WRKY transcription factors of Carica papaya in response to abiotic and biotic stresses. Mol Biol Rep 2014; 41(3): 1215-1225. PMid:24390238. http://dx.doi. org/10.1007/s11033-013-2966-8.

Pandey VC, Kumar A. Leucaena leucocephala: an underutilized plant for pulp and paper production. Genet Resour Crop Evol 2013; 60(3): 11651171. http://dx.doi.org/10.1007/s10722-012-9945-0.

Passos MAA, Lima TV, Albuquerque JL. Quebra de dormência de sementes de leucena. Rev Bras Sementes 1988; 10(2): 97-102. http:// dx.doi.org/10.17801/0101-3122/rbs.v10n2p97-102.

Pechan T, Ye L, Chang Y, Mitra A, Lin L, Davis FM, et al. A unique $33-\mathrm{kD}$ cysteine proteinase accumulates in response to larval feeding in maize genotypes resistant to fall armyworm and other lepidoptera. Plant Cell 2000; 12(7): 1031-1040. PMid:10899972. http://dx.doi. org/10.1105/tpc.12.7.1031.

Peixoto PHP, Cambraia J, SantAnna R, Mosquim PR, Moreira MA. Aluminum effects on lipid peroxidation and on the activities of enzymes of oxidative metabolism in sorghum. Rev Bras Fisiol Vegetal 1999; 11(3): 137-143.

Rani PU, Jyothsna Y. Biochemical and enzymatic changes in rice plants as a mechanism of defense. Acta Physiol Plant 2010; 32(4): 695-701. http://dx.doi.org/10.1007/s11738-009-0449-2.

Rizhsky L, Liang H, Shuman J, Shulaev V, Davletova S, Mittler R. When defense pathways collide. The response of Arabidopsis to a combination of drought and heat stress. Plant Physiol 2004; 134(4): 1683-1696. PMid:15047901. http://dx.doi.org/10.1104/pp.103.033431.
Rodríguez-Vivas RI, Alonso-Díaz MA, Rodríguez-Arevalo F, FragosoSanchez H, Santamaria VM, Rosario-Cruz R. Prevalence and potential risk factors for organophosphate and pyrethroid resistance in Boophilus microplus ticks on cattle ranches from the State of Yucatan, México. Vet Parasitol 2006; 136(3-4): 335-342. PMid:16413971. http://dx.doi. org/10.1016/j.vetpar.2005.05.069.

Roulston WJ, Stone BF, Wilson JT, White LI. Chemical control of an organophosphorus- and carbamate- resistant strain of Boophilus microplus (Can.) from Queensland. Bull Entomol Res 1968; 58(2): 379-392. http:// dx.doi.org/10.1017/S000748530005690X.

Soares AMS, Araújo SA, Lopes SG, Costa-Junior LM. Anthelmintic activity of Leucaena leucocephala protein extracts on Haemonchus contortus. Rev Bras Parasitol Vet 2015; 24(4): 396-401. PMid:26689178. http:// dx.doi.org/10.1590/S1984-29612015072.

Soares SF, Borges LMF, Braga RS, Ferreira LL, Louly CCB, Tresvenzol LMF, et al. Repellent activity of plant-derived compounds against Amblyomma cajennense (Acari: Ixodidae) nymphs. Vet Parasitol 2010; 167(1): 67-73. PMid:19897309. http://dx.doi.org/10.1016/j.vetpar.2009.09.047.

Tscharntke T, Thiessen S, Dolch R, Boland W. Herbivory, induced resistance, and interplant signal transfer in Alnus glutinosa. Biochem Syst Ecol 2001; 29(10): 1025-1047. http://dx.doi.org/10.1016/S03051978(01)00048-5.

Urbanek H, Kuzniak-Gebarowska E, Herka K. Elicitation of defense responses in bean leaves by Botrytis cinerea polygalacturonase. Acta Physiol Plant 1991; 13: 43-50.

Van der Hoorn RA, Jones JD. The plant proteolytic machinery and its role in defence. Curr Opin Plant Biol 2004; 7(4): 400-407. PMid:15231262. http://dx.doi.org/10.1016/j.pbi.2004.04.003.

Wang W, Vinocur B, Altman A. Plant responses to drought, salinity and extreme temperatures: towards genetic engineering for stress tolerance. Planta 2003; 218(1): 1-14. PMid:14513379. http://dx.doi.org/10.1007/ s00425-003-1105-5.

War AR, Paulraj MG, Ahmad T, Buhroo AA, Hussain B, Ignacimuthu $\mathrm{S}$, et al. Mechanisms of plant defense against insect herbivores. Plant Signal Behav 2012; 7(10): 1306-1320. PMid:22895106. http://dx.doi. org/10.4161/psb.21663.

War AR, Paulraj MG, Ignacimuthu S, Sharma HC. Defensive Responses in Groundnut Against Chewing and Sap-Sucking Insects. J Plant Growth Regul2013; 32(2): 259-272. http://dx.doi.org/10.1007/s00344-012-9294-4.

Xavier-Filho J, Campos FAP, Ary MB, Silva CP, Carvalho MMM, Macedo MLR, et al. Poor correlation between the levels of proteinase inhibitors found in seeds of different cultivars of cowpea (Vigna unguiculata) and the resistance/ susceptibility to predation by Callosobruchus maculatus. $J$ Agric Food Chem 1989; 37(4): 1139-1143. http://dx.doi.org/10.1021/ jf00088a071. 